\title{
Assessment of Differential Renal Function in Children with Hydronephrosis: Comparison of DMSA and MAG-3
}

\section{Hidronefrozlu Cocuklarda Separe Renal Fonksiyon/arın DMSA ve MAG-3 Sintigrafisi ile Karşılaştırılması}

\author{
Cem Akbal1, Ahmet Şahan1, Asgar Garayev1, Çağrı Akın Şekerci1, Muhammed Sulukaya1, \\ Harika Alpay2, Tufan Tarcan1, Ferruh Şimșek1
}

1 Marmara University Faculty of Medicine, Department of Urology, Istanbul, Turkey

2Marmara University Faculty of Medicine, Department of Pediatrics, Istanbul, Turkey

\section{What's known on the subject? and What does the study add?}

Of all publications in the field of urology, so far no study has demonstrated that mercaptoacetyltriglycine (MAG-3) scintigraphy is as effective as dimercaptosuccinic acid (DMSA) scintigraphy in detecting DRF. Our study demonstrates that, in the evaluation of differential renal function (DRF) in children with hydronephrosis, MAG-3 scintigraphy provides results similar to those obtained using DMSA scintigraphy and, therefore, that it can be used alone in determining DRF.

\section{ABSTRACT}

Objective

Nuclear imaging techniques such as 99mTc-dimercaptosuccinic acid (DMSA) and $99 \mathrm{mTc}-$ mercaptoacetyltriglycine (MAG-3) are widely used for the diagnosis and follow-up of urinary tract obstructions. Both imaging techniques provide the differential renal function (DRF) in slightly different ways. The aim of this study was to assess the MAG-3 scan as an adjunct or alternative to DMSA for evaluating DRF in children with hydronephrosis.

\section{Materials and Methods}

Eighty-one patients with hydronephrosis were enrolled in this study. Patient age, sex, anteroposterior renal pelvis diameter (RPD) at the time of diagnosis, parenchymal thickness and the DRF percentage found by both DMSA and MAG-3 were recorded. DMSA scintigraphy was used for detecting renal scars and estimating DRF. MAG-3 scintigraphy was used for evaluation of renal clearance, the collecting system's outflow pattern and estimating DRF.

\section{Results}

A total of 102 renal units (38 left, 22 right and 21 bilateral) were evaluated. High correlation rates were found when we compared both tests' DRF values according to antero-posterior renal pelvic diameter and patient age ( $p>0.05)$. In all groups compared in the present study, both tests demonstrated very similar results and DRF values. Statistical analysis of cut-offs $(45 \%, 40 \%, 10 \%)$ were also similar in both methods ( $p>0.05$, kappa $>0.7, r=0.926$ Pearson).

\section{ÖZET}

Amaç

${ }^{99}$ mTc-dimerkaprosüksinik asit (DMSA) sintigrafisi sepere renal fonksiyonların (SRF) hesaplanmasında altın standarttır. DMSA ve ${ }^{99} \mathrm{mTc}-$ Merkaptoasetilglisin-3 (MAG-3) böbrek sintigrafileri hidronefrozlu çocukların tanısında, izleminde ve operasyon endikasyonu belirlemede kullanılmaktadır. Her iki teknik kullanılarak SRF hesaplanabilir. Çalışmamızda hidronefrozlu çocuklarda MAG-3 sintigrafisinin DMSA sintigrafisine göre SRF'yi belirlemedeki etkinliği araştırıldı.

Gereç ve Yöntem

Ocak 2009 ile Ağustos 2013 tarihleri arasında çocuk ürolojisi kliniğimizde izlenen 81 hidronefrozlu çocuk çalışmaya dahil edildi. Çocukların tanı anındaki yaşı, cinsiyeti, renal pelvis anterior posterior (AP) çapı, parankim kalınlığı ve DMSA ile MAG-3 sintigrafisiyle belirlenen SRF'leri kaydedildi. Çocuklar SRF'ye göre \%45, \%40, \%10; AP çaplarına göre 5-10 mm, 10$20 \mathrm{~mm}, 20-30 \mathrm{~mm}$ ve $30-40 \mathrm{~mm}$ ve yaşlarına gore 24 ay altı ve üstü olarak gruplandırıldı. Gruplar her iki nükleer görüntüleme yönteminin SRF değerleri açısından karşılaştırıldı.

Bulgular

Seksen bir çocuğun (54 kız, 27 erkek) ortalama yaşı 25,9₫39,7 aydı. Toplam 102 hidronefrozlu böbreğin (38 sol, 22 sağ ve 21 çift taraflı) tanı anındaki ortalama AP çapları 22,0 mm idi (min:7, max:62). AP çapa ve yaşa göre ayrılan gruplar arası SRF değerleri her iki görüntüleme tekniği içinde benzerdi ( $p>0,05)$. Grupların SRF \%45, \%40, \%10'a göre aralarında istatistiki anlamlı fark saptanmadı ( $p>0,05$, kappa $>0,7, r=0,926$ Pearson). 


\section{ABSTRACT}

\section{Conclusion}

DMSA and MAG-3 are tests that are of assistance in the evaluation of hydronephrosis. Compared to DMSA, MAG-3 also provides valuable information to evaluate DRF values in hydronephrotic renal unit (RU). Avoiding unnecessary DMSA imaging will save time and cost and prevent over-radiation of the pediatric population.

\section{Key Words}

Kidney, hydronephrosis, MAG-3, DMSA, differential function, children

\section{ÖZET}

\section{Sonuç}

MAG-3 sintigrafisi SRF değerlendirmesinde DMSA sintigrafisi kadar etkili bir testtir. Hidronefroz ile takip edilen çocukların SRF acısından değerlendirilmesinde ve izleminde tek test olarak kullanılabilir.

\section{Anahtar Kelimeler}

Böbrek, hidronefroz, MAG-3, DMSA, separe fonksiyon, çocuk hastalar

\section{Management and Follow-Up}

For detailed evaluation, each patient underwent a physical examination. A detailed medical history was obtained and urine analysis, culture, urinary ultrasound and nuclear imaging were also performed.

\section{Urinary Ultrasound}

Since transitory neonatal dehydration lasts about 1 week after birth, all neonatal first urinary ultrasounds (US) are obtained after this period. Ultrasound should assess the anteroposterior diameter of the renal pelvis, calyceal dilatation, kidney size, thickness of the parenchyma, cortical echogenicity, ureters, bladder wall and residual urine volume.

\section{Voiding Cystourethrogram}

Children, who suffered from recurrent urinary tract infections (UTIS) and had bilateral hydronephrosis, underwent voiding-cystouretrogram (VCUG), enabling us to evaluate the uretral valves, and detect the presence of ureteroceles, diverticula and vesicoureteral reflux.

\section{Nuclear Imaging}

DMSA and MAG-3 were performed together in all patients who were enrolled in this study. DMSA scintigraphy was used for detecting renal scars and estimating DRF. MAG-3 scintigraphy was used for evaluation of renal clearance, the collecting system outflow pattern and estimating DRF. All MAG-3 scintigraphies were performed under standardized circumstances (hydration, transurethral catheter) between the fourt and sixth weeks of life or after detection of hydronephrosis by the nuclear medicine department at our hospital.

Indications for surgical intervention are an impaired DRF due to obstruction or a decrease in DRF in subsequent studies and increased anteroposterior diameter on ultrasound, and kidney detoriarationgrade IV dilatation as defined by the Society for Fetal Urology. \%10, $40 \%, 45 \%$ are important cut-off values to make surgical decisions. More than $10 \%$ difference between the two renal units ( $<45 \%$ DRF) is considered abnormal $(8,10,11)$. In the case of serial renogram results, less than $40 \%$ is the cut-off value to make the surgical decision for pyeloplasty and $10 \%$ is the cut-off value to make the surgical decision for a simple nephrectomy. The DMSA and MAG-3 DRF results of the patients were categorized according to cut-off values (10\%, 40\%, 45\%) and were later compared.

Since the kidneys complete their development during the first years of postnatal life and reach their full functional maturity in adolescence, the postnatal age criteria became important when DRF are compared for Fetal Urology guidelines for ultrasound
were used as a reference in this study (9). 
regarding to DMSA and MAG-3 results. Thus, both tests predictive for DRF according to age were also compared. Patients with urinary system anatomical abnormalities (solitary and horse shoe kidneys, duplicated system, agenetic or nephrectomize) were excluded from the study.

\section{Statistical Analysis}

Statistical analysis was performed using original SPSS software, version 20.0 (IBM Corp, NY, USA). Each test was classified as <10\%, $<40 \%$ and $<45 \%$ according to DRF values. Inter-method analyses were carried out by means of Kappa statistics. The McNemar and Mann-Whitney $U$ tests were also applied in the statistical analysis of the study where necessary. A p value of less than 0.05 was considered statistically significant.

\section{Results}

A total of 183 patients with hydronephrosis attended our pediatric urology outpatient clinic. Data of 81 of these patients were available. Fifty-four patients were male (66.7\%) and 27 were female (33.3\%). A total of 102-38 left, 22 right and 21 bilateral-hydronephrotic renal units were detected. The mean age of the patients at the time of diagnosis was $25.9 \pm 39.7$ months. Estimated mean anteroposterior RPD was $22 \mathrm{~mm}$ (min:7, max:62). Thirty-six ureteropelvic junctionplasty (UPJ-plasty), 3 ureteroneocystostomy (UNC), 3 posterior ureteral valve (PUV) ablation and 5 diagnostic cystoscopy operations were performed. Thirty-four of the patients included in this study were diagnosed with transient hydronephrosis and did not require any surgical intervention. These patients were followed using periodic ultrasound screening (Table 1). Comparison of anteroposterior RPD values measured during the follow-up by DMSA and MAG-3 RF is also presented in Table 1. In all groups compared in the present study, both tests demonstrated very similar results and DRF values. No statistically significant difference was determined between the results.

The present study also analyzed DRF within 3 groups $(\leq 45 \%, \leq 40 \%$ and $\leq 10 \%$ ) for more accurate timing of surgical intervention or follow-up. From those patients who were evaluated using DMSA, 20 renal units were detected at $\leq 45 \%, 14$ renal units at $\leq 40 \%$ and 2 renal units at $\leq 10 \%$. MAG-3 also showed similar results: 27 renal units were detected at $\leq 45 \%, 12$ renal units at $\leq 40 \%$ and 3 renal unit $\leq 10 \%$. The results in each group were compared using the McNemar test and no significant differences were found. A close correlation was determined between the DRF values obtained by these two tests (Kappa values: $0.673,0.725$ and 0.794 , respectively (substantial agreement)) (Table 2).

More detailed anteroposterior (AP) RPD statistics are summarized in Table 3. We used 5 cut-offs and assessed DRF values within 5 groups: 5-10 mm: 11 patients, $10-20 \mathrm{~mm}$ : 31 patients, 20-30 mm: 21 patients, $30-40 \mathrm{~mm}: 13$ patients and $\leq 40 \mathrm{~mm}: 5$ patients. After classification of AP RPD based on the cut offs, DRF values were assessed and DMSA-MAG-3 results were found $\mathrm{N}$ to be not statistically different ( $\mathrm{p} \geq 0.05$ ) (Table 3 ).

Sixty-six of the 81 patients were younger than 24 months at the time of diagnosis (mean: $40.4 \pm 34.2$ SD). The remaining 15 patients were older than 24 months (mean: 407.2 \pm 184.4 SD weeks). MAG-3 demonstrated similar results to those of DMSA and no statistically significant difference was found (Table 4). The scintigraphic results as obtained by MAG-3 scan were very close to those by DMSA with statistically significant correlations of DRF values $(r=0.926)$ (Figure 1$)$.

Table 1. Comparison between 99mTc-DMSA and 99mTc-MAG-3 DRF results according to hydronephrosis etiology

\begin{tabular}{|c|c|c|c|c|c|c|}
\hline & & $n$ & Right kidney DRF (\%) & Left kidney DRF (\%) & $\begin{array}{l}\text { Hydronephrotic kidney } \\
\text { APD }(\mathrm{mm})\end{array}$ & $p$ value \\
\hline \multirow{2}{*}{ Follow-up } & DMSA & 34 & $49.1( \pm 11.4)$ & $50.8( \pm 11.4)$ & \multirow{2}{*}{$16.2( \pm 9.2)$} & \multirow{2}{*}{$<0.408$} \\
\hline & MAG-3 & 34 & $48.5( \pm 12.8)$ & $51.4( \pm 12.8)$ & & \\
\hline \multirow{2}{*}{ UPJ-plasty } & DMSA & 36 & $52.6( \pm 12.0)$ & $47.6( \pm 12.7)$ & \multirow{2}{*}{$28.6( \pm 12.5)$} & \multirow{2}{*}{$<0.216$} \\
\hline & MAG-3 & 36 & $50.8( \pm 14.3)$ & $49.2( \pm 12.6)$ & & \\
\hline \multirow{2}{*}{ UNC } & DMSA & 3 & $61.6( \pm 11.5)$ & $38.3( \pm 11.5)$ & \multirow{2}{*}{$14.5( \pm 2.1)$} & \multirow{2}{*}{$<0.260$} \\
\hline & MAG-3 & 3 & $56.6( \pm 6.0)$ & $43.3( \pm 6.0)$ & & \\
\hline \multirow{2}{*}{ PUV ablation } & DMSA & 3 & $20.3( \pm 24.8)$ & $79.6( \pm 24.8)$ & \multirow{2}{*}{$22.0( \pm 9.8)$} & \multirow{2}{*}{$<0.697$} \\
\hline & MAG-3 & 3 & $21.6( \pm 22.5)$ & $78.3( \pm 22.5)$ & & \\
\hline \multirow{2}{*}{ Diagnostic cystoscopy } & DMSA & 5 & $41.6( \pm 27.0)$ & $58.4( \pm 27.0)$ & \multirow{2}{*}{$17.0( \pm 9.1)$} & \multirow{2}{*}{$<0.794$} \\
\hline & MAG-3 & 5 & $41.2( \pm 26.1)$ & $58.8( \pm 26.1)$ & & \\
\hline \multirow[t]{2}{*}{ Total } & DMSA & 81 & $49.6( \pm 14.7)$ & $50.5( \pm 15.0)$ & \multirow{2}{*}{$22.0( \pm 12.2)$} & \multirow{2}{*}{$<0.316$} \\
\hline & MAG-3 & 81 & $49.2( \pm 15.5)$ & $50.8( \pm 15.0)$ & & \\
\hline
\end{tabular}

MAG-3: Mercaptoacetyltriglycine, DMSA: Dimercaptosuccinic acid, UNC: Ureteroneocystostomy, PUV: Posterior ureteral valve, UPJ-plasty: Ureteropelvic junction-plasty, APD: Anterior-posterior diameter, DRF: Differential renal function

Table 2. DMSA and MAG-3 comparison with regard to specific DRF results ( $\leq 45 \%, \leq 40 \%$ and $\leq 10 \%$ )

\begin{tabular}{|l|l|l|l|l|}
\hline DRF/Total & DMSA DRF \% & MAG-3 DRF \% & $p$ value (McNemar test) & Kappa value \\
\hline$<45 \% /$ Total & $20 / 81(24.6 \%)$ & $27 / 81(33.3 \%)$ & $p=0.065$ & $0.673($ very good) \\
\hline$<40 \% /$ Total & $14 / 81(17.3 \%)$ & $12 / 81(14.8 \%)$ & $p=0.687$ & $0.725($ very good) \\
\hline$<10 \% /$ Total & $2 / 81(2.4 \%)$ & $3 / 81(3.7 \%)$ & $p>0.05$ & $0.794($ very good) \\
\hline \multicolumn{2}{|l|}{ MAG-3: Mercaptoacetyltriglycine, DMSA: Dimercaptosuccinic acid, DRF: Differential renal function, RPD: Renal pelvis diameter } \\
\hline
\end{tabular}




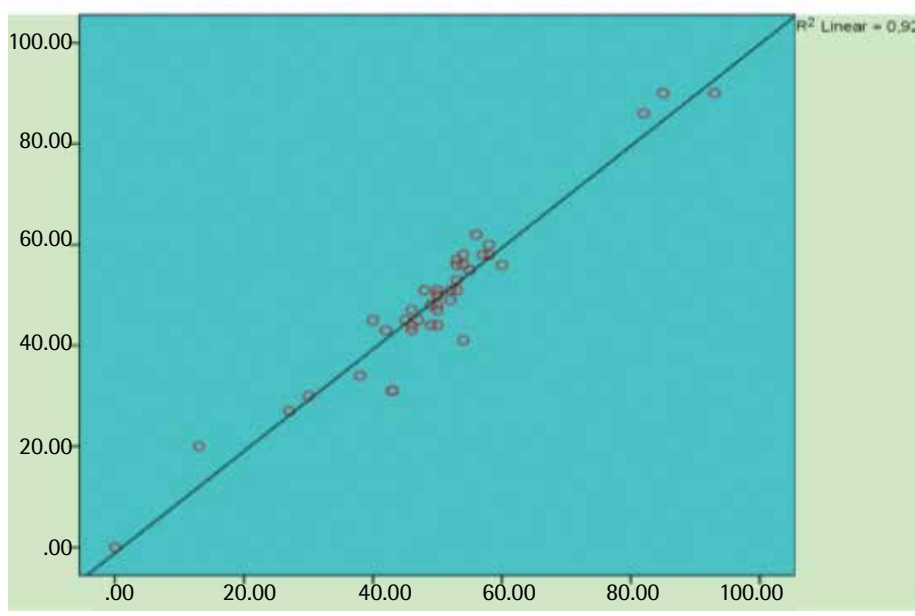

Figure 1. Kaplan meier analyses of cancer spesific survival between the groups

Tablo 3. Comparison DMSA and MAG-3 according to AP RPD and DRF

\begin{tabular}{|c|c|c|c|c|c|}
\hline \multirow{2}{*}{\multicolumn{2}{|c|}{$\begin{array}{l}\text { Anteroposterior RPD } \\
\text { (mean) }\end{array}$}} & \multirow{2}{*}{$\mathrm{n}$} & \multicolumn{2}{|c|}{ DRF $(\%)$} & \multirow{2}{*}{$p$ value } \\
\hline & & & (right kidney) & (left kidney) & \\
\hline \multirow{2}{*}{ 5-10 mm } & DMSA & \multirow{2}{*}{11} & 48.5 & 51.5 & \multirow{2}{*}{0.929} \\
\hline & MAG-3 & & 48.6 & 51.4 & \\
\hline \multirow{2}{*}{$10-20 \mathrm{~mm}$} & DMSA & \multirow{2}{*}{31} & 50.1 & 50.1 & \multirow{2}{*}{0.752} \\
\hline & MAG-3 & & 50.3 & 49.6 & \\
\hline \multirow{2}{*}{$20-30 \mathrm{~mm}$} & DMSA & \multirow{2}{*}{21} & 51.3 & 49.6 & \multirow{2}{*}{0.050} \\
\hline & MAG-3 & & 53.5 & 48.3 & \\
\hline \multirow{2}{*}{$30-40 \mathrm{~mm}$} & DMSA & \multirow{2}{*}{13} & 49.6 & 50.3 & \multirow{2}{*}{0.399} \\
\hline & MAG-3 & & 48.3 & 51.6 & \\
\hline \multirow{2}{*}{$40 \mathrm{~mm}$} & DMSA & \multirow{2}{*}{5} & 52.4 & 47.6 & \multirow{2}{*}{0.522} \\
\hline & MAG-3 & & 56.2 & 43.8 & \\
\hline
\end{tabular}

MAG-3: Mercaptoacetyltriglycine, DMSA: Dimercaptosuccinic acid,

DRF: Differential renal function, RPD: Renal pelvis diameter, AP: Anteroposterior

Table 4. Patients age at the time of diagnosis and comparison of results

\begin{tabular}{|l|l|l|l|l|l|}
\hline \multicolumn{2}{|l|}{ Age } & Mean & $n$ & $\begin{array}{l}\text { Std. } \\
\text { deviation }\end{array}$ & $p$ value \\
\hline \multirow{3}{*}{$<24$ month } & DMSA & 47.6 & 66 & 34 & \\
\cline { 2 - 6 } & MAG-3 & 47.5 & 66 & 34 & 0.923 \\
\hline \multirow{3}{*}{$>24$ month } & DMSA & 53.3 & 15 & 184 & \\
\cline { 2 - 6 } & MAG-3 & 51.4 & 15 & 184 & 0.193 \\
\hline \multicolumn{7}{|l|}{ MAG-3: Mercaptoacetyltriglycine, DMSA: Dimercaptosuccinic acid } \\
\hline
\end{tabular}

\section{Discussion}

DMSA and MAG-3 are tests that are of assistance in the evaluation of hydronephrosis and that are often employed together during the clinical decision making process (8). Although the pharmacokinetic properties of the nuclear agents employed in the two tests differ, both tests predict the separated renal functions $(12,13)$. In the present study, it was concluded that in the case of patients for which DMSA and MAG-3 are utilized regardless of the etiology of hydronephrosis, considering separated renal functions and variables such as patient age, the degree of hydronephrosis and etiology is believed to separate the two tests; in the clinical setting, MAG-3 can be employed in place of DMSA. A statistically significant difference was not detected between the two tests when they were compared based on hydronephrosis degree and etiology and patient age. The two tests were also found to be highly similar and compatible when compared in terms of clinical applicability.

The subject of the present study arose from a desire to minimize radionuclide evaluation in the pediatric patient population. In this study, the aim was to compare the results obtained using DMSA and MAG-3 and contrast management in the different conditions of hydronephroticrenal units such as transient hydronephrosis, ureteropelvic junction obstruction (UPJO), vesicoureteric reflux (VUR), posterior urethral valve (PUV), ectopic ureter based on DRF values.

DMSA is a radionuclide molecule that enters the proximal and distal tubules of the kidney. For this reason, it is a method of choice for cortical assessment. MAG-3 is mostly excreted by the proximal tubules; it enters the collecting systems and leaves the kidneys very fast. DMSA scan is usually performed 2-3 hours after the DMSA injection. But MAG-3 images are obtained immediately after the injection of MAG-3. Both techniques, therefore, estimate the kidneys contribution to total renal function in slightly different ways.

In the evaluation of hydronephrosis, assessment of DRF is essential to provide a prognosis or to determine whether to perform surgery. Although DMSA scan is the most reliable method in measuring DRF (4), the long residence time in the renal cortex results in overradiation of the children who have to attend nuclear medicine clinic twice for later scanning. In addition, evaluation by means of DMSA is limited to only cortical assessment, not the collecting system outflow pattern $(3,4,14)$. Other agents, such as MAG-3, also measure DRF and are employed in the evaluation of renal clearance. MAG-3 is cleared from the blood by the renal tubules and excreted into the collecting system $(15,16)$. Therefore, it is possible to evaluate renal perfusion, tubular function, tubular secretion to the collecting system and the urodynamics of the collecting system by means of MAG-3. Thity minutes after injection, most tracer activity leaves the kidney, which is an important advantage of this technique as it makes the radiation dose received by the patient less than that received by a patient undergoing a DMSA scan. It should also be noted that MAG-3 takes less time and requires less follow-up visits. The radiation exposure for a DMSA study is approximately ten times higher than that for a MAG3 study, thus, eliminating the need for the DMSA study will reduce radiation exposure. This change in practice would, therefore, result in considerable savings in time, cost and radiation burden (13).

When previously published studies on this topic are reviewed, one comes to see that there have been many studies comparing the correlation between these two techniques. However, to our knowledge, all such similar studies have been published in nuclear medicine or radiology journals. None of them include clinical prognosis of the disease $(13,17,18,19)$. In addition, worldwide, no such article has been published by a pediatric urology clinic. 
The first published articles comparing the two techniques, DMSA and MAG-3, included only a few patients. Piepszet et al.(12) performed and evaluated both test on healthy volunteers. As a result, they found similar results.

Aktaş et al. (17) compared MAG-3 and DMSA RRF estimations and assessed the reproducibility of these estimations in children with unilateral hydronephrosis. Their results showed that DMSA and MAG 3 were correlated for both time intervals and for observers. DRF estimation can be a problem in infants and in patients with higher grades of hydronephrotic kidney. Only comparison with 45\% was slightly different in each test (17). Consequently, it is determined that both screening techniques gave us similar results for follow-up and for timing of operations. Therefore, we support that both techniques can be used alone for further evaluations.

Ritchie et al. (13) compared DRF values calculated using 99mTc-DMSA and those calculated using 99mTc-MAG-3 in pediatric patients and again found good correlation between DMSA and MAG-3.

In the present study, the mean DRF of the left unit with $99 \mathrm{mTc}$ DMSA was 48.9\% (SD 16.4) and was 49.6\% (SD 15.6\%) using $99 \mathrm{mTc}-$ MAG-3. Thus, both tests showed a significant correlation with each other. There was a lack of consistency between DRF estimations or supranormal functions only in a limited number of cases (Tables 1, 4). The measurement of DRF can be overestimated by $99 \mathrm{mTc}-\mathrm{MAG}-3$ in the affected kidneys (5).

Although many decisions regarding surgery are based on the functional changes detected by serial diuretic renography evaluations, the ability of MAG-3 in estimating DRF has been questioned. In follow-up, DRF values of 10\%, 40\%, 45\% are important cut-off values to make surgical decisions. More than 10\% difference between the two renal units $(<45 \%$ DRF) is considered an abnormal test result $(8,10,11)$. According to serial renogram, less than $40 \%$ is the cut-off value to make a surgical decision for ureteroplasty and $10 \%$ is the cut-off value to make a surgical decision for simple nephrectomy. In the present study, there were no statistically significant differences in prognosis and management based on the values presented by the two nuclear imaging methods. Only 2 patients presented dissimilar results according to DRF 40\% (DMSA: 39\% and 39\% vs MAG-3: 43\% and 45\%, respectively) and 1 patient according to 10\% (DMSA: 4\% vs MAG-3: 15\%). Renal cortical thickness, pelvic anterior-posterior diameter (APD), urine and blood tests do not contribute to follow-up results.

In the calculation of clearance adjusted according to the body mass index during childhood, those kidneys that demonstrated progressive maturation until the third week, drew a plateau until year 1, appeared to grow 1.5 times in size by year 2 and later appeared to become fixed (20). In the present study, values obtained in 24 months were compared and there were similar test results in each test. Regardless of whether the kidney completes maturation or not, their power is unchanging in determining separated renal functions.

\section{Study Limitations}

Our study included a small number of patients with low renal function (at $\leq 40 \%$ and at $\leq 10 \%$ ).

\section{Conclusion}

The results suggest that in routine clinical management and follow up, MAG-3 scan will provide accurate DRF, similar to that with DMSA. MAG-3 provides additional information on the urodynamics of the urinary tract avoiding unnecessary radiation exposure besides being timesaving. The results of MAG-3 do not change the clinical decision on the management of the condiditon and patient followup. Therefore, it is possible to regard the $99 \mathrm{mTc}-\mathrm{MAG}-3$ as adequate in evaluating DRF as an initial screening test in children with various renal disorders. The ${ }^{99} \mathrm{mTc}$ DMSA scan is the only suitable in doubtful cases such as those involving small cortical focal defects.

Ethics Committee Approval: The study were approved by the Marmara University of Local Ethics Committee, Informed Consent: Consent form was filled out by all participants, Concept: Cem Akbal, Tufan Tarcan, Ferruh Şimşek, Design: Cem Akbal, Tufan Tarcan, Ferruh Şimşek, Data Collection or Processing: Ahmet Şahan, Asgar Garayev, Çağrı Akın Şekerci, Harika Alpay, Analysis or Interpretation: Ahmet Sahan, Cem Akbal, Literature Search: Ahmet Sahan, Asgar Garayev, Writing: Cem Akbal, Ahmet Şahan, Peer-review: Internal peerreviewed, Conflict of Interest: No conflict of interest was declared by the authors, Financial Disclosure: The authors declared that this study has received no financial support.

\section{References}

1. Koff SA. Problematic ureteropelvic junction obstruction. The Journal of urology. 1987;138:390.

2. Gordon I, Anderson PJ, Lythgoe MF, Orton M. Can technetium-99mmercaptoacetyltriglycine replace technetium-99m-dimercaptosuccinic acid in the exclusion of a focal renal defect? Journal of nuclear medicine : official publication, Society of Nuclear Medicine. 1992;33:2090-2093.

3. Gungor F, Anderson P, Gordon I. Effect of the size of regions of interest on the estimation of differential renal function in children with congenital hydronephrosis. Nuclear medicine communications. 2002;23:147-151.

4. Lythgoe MF, Gradwell MJ, Evans K, Gordon I. Estimation and relevance of depth correction in paediatric renal studies. European journal of nuclear medicine. 1998;25:115-119.

5. Othman S, Al-Hawas A, Al-Maqtari R. Renal cortical imaging in children: 99mTc MAG3 versus 99mTc DMSA. Clinical nuclear medicine. 2012;37:351-355.

6. Rossleigh MA. Renal cortical scintigraphy and diuresis renography in infants and children. Journal of nuclear medicine : official publication, Society of Nuclear Medicine. 2001;42:91-95.

7. Mandal S, Goel A, Singh MK, Kathpalia R, Nagathan DS, Sankhwar SN, et al. Clavien classification of semirigid ureteroscopy complications: a prospective study. Urology. 2012;80:995-1001.

8. Ardela Diaz E, Miguel Martinez B, Gutierrez Duenas JM, Diez Pascual R, Garcia Arcal D, Dominguez Vallejo FJ. [Comparative study of differential renal function by DMSA and MAG-3 in congenital unilateral uropathies]. Cirugia pediatrica : organo oficial de la Sociedad Espanola de Cirugia Pediatrica. 2002;15:118-121.

9. Fernbach SK, Maizels M, Conway JJ. Ultrasound grading of hydronephrosis: introduction to the system used by the Society for Fetal Urology. Pediatric radiology. 1993;23:478-480.

10. Buscher HP, Meder I, MacNelly S, Gerok W. Zonal changes of hepatobiliary taurocholate transport in intrahepatic cholestasis induced by 17 alphaethinyl estradiol: a histoautoradiographic study in rats. Hepatology. 1993;17:494-499. 
11. Tapia J, Gonzalez R. Pyeloplasty improves renal function and somatic growth in children with ureteropelvic junction obstruction. The Journal of urology. 1995;154:218-222.

12. Piepsz A, Tondeur M, Ham H. Relative 99mTc-MAG3 renal uptake: reproducibility and accuracy. Journal of nuclear medicine : official publication, Society of Nuclear Medicine. 1999;40:972-976.

13. Ritchie G, Wilkinson AG, Prescott RJ. Comparison of differential renal function using technetium-99m mercaptoacetyltriglycine (MAG3) and technetium-99m dimercaptosuccinic acid (DMSA) renography in a paediatric population. Pediatric radiology. 2008;38:857-862.

14. Groshar D, Embon OM, Frenkel A, Front D. Renal function and technetium99m-dimercaptosuccinic acid uptake in single kidneys: the value of in vivo SPECT quantitation. Journal of nuclear medicine : official publication, Society of Nuclear Medicine. 1991;32:766-768.

15. Conway JJ, Maizels M. The "well tempered" diuretic renogram: a standard method to examine the asymptomatic neonate with hydronephrosis or hydroureteronephrosis. A report from combined meetings of The Society for Fetal Urology and members of The Pediatric Nuclear Medicine
Council--The Society of Nuclear Medicine. Journal of nuclear medicine : official publication, Society of Nuclear Medicine. 1992;33:2047-2051.

16. Schaap GH, Alferink TH, de Jong RB, Oe PL, Roos JC, Donker AJ. 99mTcMAG3: dynamic studies in patients with renal disease. European journal of nuclear medicine. 1988;14:28-31.

17. Aktas GE, Inanir S. Relative renal function with MAG-3 and DMSA in children with unilateral hydronephrosis. Annals of nuclear medicine. 2010;24:691-695.

18. Caglar M, Gedik GK, Karabulut E. Differential renal function estimation by dynamic renal scintigraphy: influence of background definition and radiopharmaceutical. Nuclear medicine communications. 2008;29:1002-1005.

19. Lythgoe MF, Gordon I, Khader Z, Smith T, Anderson PJ. Assessment of various parameters in the estimation of differential renal function using technetium-99m mercaptoacetyltriglycine. European journal of nuclear medicine. 1999;26:155-162.

20. Lythgoe MF, Gordon I, Anderson PJ. Effect of renal maturation on the clearance of technetium-99m mercaptoacetyltriglycine. European journal of nuclear medicine. 1994;21:1333-1337. 